\title{
Review \\ Applicability of Honey on Silkworms (Bombyx mori) and Quality Improvement of Its Biomaterials
}

\author{
Gabriela-Maria Baci * ${ }^{\mathbb{D}}$, Alexandra-Antonia Cucu $\left(\mathbb{D}\right.$, Adela Ramona Moise $\mathbb{( 1 D}^{\circ}$ and Daniel Severus Dezmirean \\ Faculty of Animal Science and Biotechnology, University of Animal Sciences and Veterinary Medicine \\ Cluj-Napoca, 400372 Cluj-Napoca, Romania; antonia.cucu@usamvcluj.ro (A.-A.C.); \\ adela.moise@usamvcluj.ro (A.R.M.); ddezmirean@usamvcluj.ro (D.S.D.) \\ * Correspondence: gabriela-maria.baci@usamvcluj.ro
}

check for updates

Citation: Baci, G.-M.; Cucu, A.-A.;

Moise, A.R.; Dezmirean, D.S.

Applicability of Honey on Silkworms (Bombyx mori) and Quality Improvement of Its Biomaterials. Appl. Sci. 2021, 11, 4613. https:// doi.org/10.3390/app11104613

Academic Editor: Jerzy Wilde

Received: 28 April 2021

Accepted: 17 May 2021

Published: 18 May 2021

Publisher's Note: MDPI stays neutral with regard to jurisdictional claims in published maps and institutional affiliations.

Copyright: (c) 2021 by the authors. Licensee MDPI, Basel, Switzerland. This article is an open access article distributed under the terms and conditions of the Creative Commons Attribution (CC BY) license (https:// creativecommons.org/licenses/by/ $4.0 /)$.

\begin{abstract}
Since ancient times, honey has been considered one of the most illustrious and esteemed natural products. Honey plays two key roles; specifically, it is an appreciated nutritional product, and also exhibits a wide range of beneficial properties for human health as a therapeutic agent. Furthermore, it has been shown that honey has valuable effects on the biological and physiological features of mulberry silkworms (Bombyx mori). Bombyx mori exhibits importance not only for the economy, but it also serves as an important biotechnological bioreactor for the production of recombinant proteins that have a great impact in the medical field and beyond. It also represents an important model organism for life sciences. In view of the fact that silk fibroin serves as a natural biopolymer that displays high biocompatibility with human organisms and due to honey's various and remarkable properties for human health, the two elements are currently used together in order to develop ideal biomaterials for a wide range of purposes. In this review, by discussing the applicability of honey on Bombyx mori and beyond, the importance of honey for life sciences and related fields is spotlighted.
\end{abstract}

Keywords: honey; mulberry silkworms; applicability; biomaterials; silk fibroin

\section{Introduction}

Honey represents one of the most valued natural products that exhibit a great impact on human nutrition and health. It has been used since ancient times in various forms to sweeten and flavor different types of foods [1]. Furthermore, honey has been used for therapeutic purposes in order to treat or to prevent several clinical conditions, such as dermatitis, diabetes or cancer [2]. Honey possesses a wide range of curative properties due to the presence of more than 200 bioactive compounds. By using flower nectar, honeybees perform considerable work in order to obtain this appreciable natural product [3]. The nectar source dictates the physical properties of honey, such as flavor, odor and color. Furthermore, the geographical origins also exhibit an impact on honey's features. It has also been shown that the floral source and the geographical origin regulate the most important therapeutic effect of honey, specifically the antimicrobial activity [1]. Moreover, honey represents an important alternative agent against antibiotic resistant bacteria. Hydrogen peroxide $\left(\mathrm{H}_{2} \mathrm{O}_{2}\right)$ is the main compound that is responsible for the antibacterial activity. However, several types of honey have this prominent feature, even if the catalase neutralizes their hydrogen peroxide, suggesting that there are more active compounds that generate antibacterial activity [2,4]. In this direction, Dezmirean et al. highlighted the key role played by heather honey against several microorganisms that represent a threat for human health. Besides the content of hydrogen peroxide, heather honey exhibits antibacterial activity due to its low acidity, the presence of polyphenolic compounds and due to its high osmotic concentration [5].

As insects that are native to China, mulberry feeding silkworms (Bombyx mori) represent key players for the global economy. Bombyx mori is of great importance due to silk production. The silk gland of Bombyx mori exhibits three different regions, namely 
the anterior silk gland (ASG), the middle silk gland (MSG) and the posterior silk gland (PSG) [6]. Silk is an organic polymer with a wide range of extraordinary properties [7], such as elasticity, high strength, and toughness, but also displays an extraordinary level of biocompatibility with human organisms. Regarding the composition of silk, it contains two main proteins, fibroin and sericin, as well as an alcohol-soluble organic matter, in small amounts. The sericin is synthesized in the MSG, and the fibroin in the PSG [6]. Morphologically, silk involves two fibroin threads that are held together by sericin [8,9]. Owning a wide range of extraordinary features, silk fibroin is currently used to develop various biomaterials with a great impact for the medical field [10]. In this direction, silkworms exhibit a great advantage; specifically, they have a short-term replication cycle (with an incubation period of 14 days) which includes several phases of growth, namely, egg, larvae, pupa, moth [11]. Presently, extraordinary advancements in the medical field are being made and by considering this situation, there is a great need for affordable sustainable biomaterials. The classic synthetic materials that are used in the medical and pharmaceutical field do not display the same remarkable physical and biologic properties as silk. Currently, silk exhibits numerous applications in these fields; for instance, it has been used for decades as surgical mesh and suture thread [12]. In order to overcome the limitations of polymeric synthetic biomaterials, there have been described several silk-based biomaterials (Table 1).

Table 1. The advantage of using silk-based biomaterial compared to synthetic polymers.

\begin{tabular}{|c|c|c|c|}
\hline Synthetic Polymer & $\begin{array}{l}\text { Homologous Silk } \\
\text { Based Biomaterial }\end{array}$ & $\begin{array}{l}\text { Advantages of Silk } \\
\text { Based Biomaterials }\end{array}$ & Reference \\
\hline $\begin{array}{l}\text { Metal-based } \\
\text { microneedle }\end{array}$ & Silk microneedles & Controlled drug release & [13] \\
\hline Gauze & $\begin{array}{l}\text { Silk fibroin nanoparticles } \\
\text { hydrocolloid dressings }\end{array}$ & Accelerated wound healing & [14] \\
\hline Polypropylene & Fibroin & $\begin{array}{c}\text { Increased cell adhesion } \\
\text { and viability }\end{array}$ & [15] \\
\hline Su 8 & $\begin{array}{l}\text { Photo-cross-linkable } \\
\text { silk fibroin }\end{array}$ & $\begin{array}{l}\text { Higher-level affinity } \\
\text { towards neurons }\end{array}$ & [16] \\
\hline
\end{tabular}

Silk production is not the only reason for which Bombyx mori receives great attention from the scientific community. Bombyx mori plays a pivotal role as a model organism due to its remarkable characteristics $[11,17,18]$. There are numerous studies that highlight the advantages of using silkworms as a model organism in life science. For instance, Zhang et al., used Bombyx mori to analyze the effect of several therapeutic drugs for hyperuricemia and gout treatment [19]. Moreover, silkworms are currently used for environmental monitoring due to Bombyx mori's high sensitivity to pollution [17].

It is a well-known fact that Bombyx mori's biological parameters are determined by the nutritional value of the mulberry leaves. In this direction, it has been shown that the use of honey increases the nutritional value of mulberry leaves, and therefore, honey exhibits a great advantage for the economic features of Bombyx mori [20]. Furthermore, honey plays a key role in the biomaterials field. It is currently used as an additive in silk-fibroin-based biomaterials due to its hygroscopic and antibacterial properties. There have been described a wide range of biomaterials that consist of silk fibroin and honey [21]. In this context, this review, by highlighting the impact of honey on Bombyx mori and its biomaterials, may contribute to revealing new directions for the applicability of honey in different fields. Thus, this could represent a starting point for future research. Even if the subject of this paper has not yet been massively approached, it is innovative and exerts extraordinary importance for the field of life science.

\section{The Impact of Honey on Bombyx mori Biological and Technological Traits}

Mulberry leaves are the only natural food source in terms of Bombyx mori nourishment. Mulberry leaves represent both the source of water and the source of nutrients necessary 
for growth and development stages [22]. The availability of the silkworms' nourishment source is limited; specifically, it is available only in the spring-summer season. Due to the great potential of Bombyx mori in sericulture, agriculture or in the pharmaceutical industry, the restricted availability of mulberry leaves represents a great impediment. In this regard, there have been described several artificial diets for Bombyx mori in order to facilitate and to overcome the impediment of season-restricted rearing. The artificial diets are not climate-change impacted and are also pathogen-free. These two features have a significant impact on the use of silkworms in life science fields [23,24].

Honey, as a natural sweetening agent, is mainly composed of water and several types of sugars, such as glucose, fructose and sucrose [25]. The composition of honey also involves a small proportion of vitamins, enzymes, amino acids, minerals or phenolic compounds $[26,27]$. Regarding the enzymes that are found in honey, there are three key players, namely invertase, diastase and glucose oxidase. Of the three enzymes, the most outstanding is the invertase or the $\alpha$-glucosidase. Being an exo-carbohydrase, by converting sucrose, it generates two monosaccharides, specifically glucose and fructose [28,29].

Recognizing honey's prominent effects based on its compounds, particularly due to the enzymes' presence, Bhatti et al. carried out a study in order to analyze the impact of rearing silkworms with honey-dipped mulberry leaves. The authors closely observed the effects of a honey-enriched diet on larval growth. They also hypothesized that honey could have an impact on the silk cocoon yield. There were used two groups of Bombyx mori larvae: one experimental group and one control group. The mulberry leaves received by the experimental group were dipped in advance in an aqueous solution that contained $2 \%$ honey. The treatment was applied for 4 days. Specifically, the larvae of silkworms received honey-dipped mulberry leaves on days 1,3, 5 and 7, and on days 2, 4, 6 and 8, they received just mulberry leaves [30].

Surprisingly, in the first instance, after day 1, the silkworms included in the experimental group did not consume more mulberry leaves than the control group. Nevertheless, after days 3, 5 and 7, differences could be observed between the two groups. Specifically, the experimental group left fewer uneaten leaves than the control group, suggesting that Bombyx mori has a predisposition for eating honey-enhanced leaves [30].

Taking into consideration the complex composition of honey and the beneficial effects that its compounds manifest on a large spectrum of disorders, including digestive diseases, one can assume its important role in Bombyx mori nutritional aspects [31,32]. In this direction, the results of the study showed that by adjoining honey with the mulberry leaves, the digestive capacity of the experimental group was better compared with the digestive function of the control group. Furthermore, higher weight gain was observed in the experimental group, particularly of $348.23 \%$, than in the other group that exhibited a weight gain of $204.54 \%$. When it came to cocoon parameters, by dipping the mulberry leaves in an aqueous honey solution, it was observed that Bombyx mori formed the cocoon earlier, but also it was noticed that the cocoon shape was more uniform and the weight was higher in the experimental group [30].

Nevertheless, a study was performed that investigated the impact of a honey-enriched traditional diet on the Bombyx mori digestive metabolism, both on the digestive substrates and digestive enzymes. It was demonstrated that the Bombyx mori digestive metabolism is based on the Hutchinson's principle, namely that during larval development, digestive substrates, such as proteins or cellulose, are accumulated in the gut wall cells, while the activity of the digestive enzymes are reduced. This study revealed that by supplementing with honey the traditional food of Bombyx mori, there was a significant growth when it came to substrate accumulation in the gut wall cells and a noticeable decline in the level of digestive enzymes. Their data showed that by adding honey in the silkworms' diet during the larval stages, the amount of total proteins found in the midgut recorded a significant increase, specifically from $1.04 \mathrm{mg} / \mathrm{g}$ it to $10.25 \mathrm{mg} / \mathrm{g}$. In addition, by observing the protease activity, they noticed that it was much lower due to the addition of honey, namely it was $0.02 \mu \mathrm{m}$ proteins $/ \mathrm{h}$ from $0.28 \mu \mathrm{m}$ proteins $/ \mathrm{h}$. In regard to the gut wall 
tissue, there was also an observed increase when it came to the total protein content, from $11.09 \mathrm{mg} / \mathrm{g}$ to $15.56 \mathrm{mg} / \mathrm{g}$. Once again, the advantages of adding honey in Bombyx mori's diet were underlined [33].

Along the same line, another study investigated the minimum effective concentration of honey as an exogenous nutrient that is needed for Bombyx mori to acquire optimal larval growth and a substantial metabolic rate. The authors observed that the minimum effective concentration is tissue specific. They demonstrated that the concentration of honey is a key parameter, more specifically, while $2 \%$ honey is the optimal concentration for ideal larvae growth, $1 \%$ honey is required to acquire an optimal metabolism rate [34].

Keeping in view the optimal concentration of $2 \%$ honey for ideal larval growth, [34], another study was performed in order to investigate the impact of a honey-enriched diet on several parameters of Bombyx mori. They examined the honey's effect on the feeding patterns and proteins profiles, but on the larval and silk gland growth as well. By comparing the silk gland weight $(\mathrm{g})$ of the group that received the traditional mulberry diet and the silk gland weight of the group that was fed the honey-enriched mulberry leaves, their data showed that by adding honey into the silkworms' diet, a great improvement was observed (Table 2) [35].

Table 2. The effect of honey-enriched diet on silk gland weight (g) [35].

\begin{tabular}{|c|c|c|}
\hline \multirow{2}{*}{ 5th Instar Day } & Control Group & Experiment Group \\
\hline & \multicolumn{2}{|c|}{ Silk Gland Weight (g) } \\
\hline 1 & 0.018 & 0.018 \\
\hline 3 & 0.092 & 0.105 \\
\hline 5 & 0.182 & 0.280 \\
\hline 7 & 0.350 & 0.430 \\
\hline
\end{tabular}

In regard to the three distinct regions of the silk gland, the authors compared the protein profiles and concluded that honey exhibits a remarkable influence. The most outstanding impact of the honey-supplemented diet on the protein profiles was observed in the PSG. There was a great difference between the control and the experimental group. Specifically, the mean of the total protein profiles $(\mathrm{mg} / \mathrm{g})$ of the control group on day 7 was 50.75 and the mean of the experimental group was 64.27. Their results demonstrate that by including honey in the silkworms' diet, productivity and, more importantly, the quality of the silk are enhanced. On the other hand, the author investigated the honey's impact on various economic parameters, such as shell protein, floss weight, floss protein, raw silk weight and so on. As expected, the experimental group revealed increased values, compared with the control group, for each parameter, emphasizing once again the advantage of using this sweetening agent in the silkworms' diet [35].

Tamilselvi et al. carried out an experiment that aimed to analyze the impact of honey on various economic parameters of Bombyx mori. By supplementing the mulberry leaves with different types of honey, they analyzed the changes that occurred among the economic characteristics of Bombyx mori (Table 3) [20].

Their results confirmed that honey is a reliable and promising additional nutrient for Bombyx mori. Thus, honey exhibits a powerful influence on various economic traits of silkworms, such as growth, silk production and metabolism. When it comes to comparing the different types of honey utilized, by adding T. iridipennis honey, the best results were observed [20].

On the same line, another experiment, aiming to analyze the applicability and the impact of honey on Bombyx mori's genetic and economic traits, revealed that honey also exhibits a protective effect for silkworms against several diseases [36]. Furthermore, it was reported that honey has a positive effect on the rate of deposited eggs. In this direction, the group that received honey as a nutritional supplement exhibited a $36.5 \%$ higher rate compared to the control group [37]. 
Table 3. The impact of honey produced by different honey bees on the economic parameters of Bombyx mori [20].

\begin{tabular}{ccccc}
\hline Honey Sources & $\begin{array}{c}\text { Larval Weight } \\
(\mathbf{g})\end{array}$ & $\begin{array}{c}\text { Cocoon Weight } \\
(\mathbf{g})\end{array}$ & $\begin{array}{c}\text { Filament Length } \\
(\mathbf{m})\end{array}$ & $\begin{array}{c}\text { Shell Weight } \\
\text { (g) }\end{array}$ \\
\hline Apis cerana & 2.98 & 1.34 & 1214.35 & 0.284 \\
Apis florea & 3.07 & 1.42 & 1235.13 & 0.296 \\
Apis mellifera & 3.22 & 1.45 & 1273.4 & 0.308 \\
Apis dorsata & 3.32 & 1.47 & 1278.38 & 0.33 \\
Trigona iridipennis & 3.44 & 1.59 & 1312.15 & 0.372 \\
Control & 2.89 & 1.34 & 1198.75 & 0.257 \\
\hline
\end{tabular}

Additionally, another study pointed out the beneficial effects of a honey-enriched diet on silkworms' biological and reproductive characteristics. The researchers aimed to investigate the effect of this natural additive on the production yield of silk and eggs. They analyzed the impact of carob honey, citrus honey and also palm pollen. The three elements were analyzed alone but also they were blended in different combinations. Their results showed that the mixture between citrus honey and palm pollen exhibits the most significant positive impact on the silkworms' studied parameters. In this study each experiment was replicated three times and three different concentrations of each type of honey were analyzed, specifically, $1 \mathrm{~mL}, 3 \mathrm{~mL}$ and $5 \mathrm{~mL}$. By comparing the impact of the two types of honey analyzed, in regard to the number of eggs, the citrus honey $(5 \mathrm{~mL})$ exhibited the best results (Table 4) [38].

Table 4. The impact of different concentrations of carob honey and citrus honey on the number of eggs of Bombyx mori [38].

\begin{tabular}{cc}
\hline Type of Honey $(\mathbf{m L})$ & Number of Eggs \\
\hline Carob honey 1 & 122.67 \\
Carob honey 3 & 178.33 \\
Carob honey 5 & 263 \\
Citrus honey 1 & 286 \\
Citrus honey 3 & 365 \\
Citrus honey 5 & 429.67 \\
Control & 417.33 \\
\hline
\end{tabular}

In complete agreement, in regard to the number of deposited eggs, another experiment demonstrated the outstanding benefits of using honey-enriched food on Bombyx mori's yield. In this case, three types of honey were studied, both alone and in different mixtures: carob honey, seder honey and black cumin honey (Table 5) [39].

Table 5. The impact of three types of honey on the number of deposited eggs of Bombyx mori [39].

\begin{tabular}{cc}
\hline Type of Honey & Number of Eggs \\
\hline Carob honey & 558.6 \\
Seder honey & 563.8 \\
Black cumin honey & 494.6 \\
Black cumin honey/Seder honey & 459 \\
Control & 393 \\
\hline
\end{tabular}

Additionally, another research study demonstrated that the economic traits of Bombyx mori were enhanced when honey was included as an additive to the mulberry leaves in the silkworms' nutrition. They examined the effect of different camphor honey concentrations on several biological aspects, such as larval weight and silk gland weight, but also technological aspects were studied, such as cocoon weight, cocoon shell weight, silk content ratio and filament length [40]. 
Keeping in mind the great advances that have been made by using next-generation sequencing techniques, there have been performed numerous studies regarding the gut microbiome of a wide range of organisms. As silkworms represent important experimental model organisms in the life science fields, Chen et al. exhaustively characterized their gut microbiota. Surprisingly, their results showed that even if, for reproduction and survival, the silkworms are dependent on humans, their gut microbiota comprise numerous bacteria. In this direction, it has been suggested that non-pathogenic microorganisms have a positive impact on the host's growth [41]. Recently it was demonstrated that gut bacteria increase the silkworms' resistance against organophosphate insecticides [42]. In this direction, the results of the study showed that by adding honey to the mice's diet, there was observed a great impact on the amount of lactobacilli and bifido bacteria [43]. Knowing this, adding honey to the silkworms' diet may have a great impact on the number of gut members and, therefore, on the silkworms' nutrition and resistance against insecticides. By improving the silkworms' growth and resistance to certain insecticides, the economic traits might be affected in a positive way.

\section{The Impact of Honey on Silk Fibroin-Based Biomaterials}

\subsection{Honey as a Medicine}

\subsubsection{Antibacterial Activity}

Of the broad-spectrum of extraordinary therapeutic characteristics of honey, the most outstanding beneficial property, but also the most investigated one, is the antibacterial activity. Even though the revolutionary discovery of antibiotics decreased interest in honey in terms of medical use [44,45], nowadays, due to the high resistance of countless bacterial strains to antibiotics, this remarkable natural product has gained much more attention in the scientific community [46].

In the literature, there are mentioned several factors that are relevant to honey's strong bactericidal activity [47]. An important characteristic of honey is that it possesses a low water content [48]. This aspect exhibits great importance due to the fact that in order to grow, microorganisms require water. However, there are several strains of bacteria that are able to grow despite the reduced quantity of water. For instance, Staphylococcus aureus (S. aureus) possesses this capacity, but it has been also shown that by using honey, the bacteria's growth is inhibited [49]. In addition, Mama et al. successfully demonstrated the bacteriostatic and bactericidal effect of honey on S. aureus methicillin-resistant strains. This finding suggests that not only the low water content is responsible for honey's inhibitory activity [46].

Being the majority constituents in honey, the high amounts of sugars have a key role in fulfilling the antibacterial activity by dehydrating bacterial cells through the process of osmosis. However, by using honey in order to combat wound infections, the antibacterial activity is reduced due to the fact that when it comes to the human body, there are body fluids that dilute the honey [50,51].

There are small quantities of organic acids in honey's composition, and these elements are important players for honey's acidic pH [52]. Having a pH between 3.2 and 4.5 [53], honey is not an appropriate medium for bacterial growth since most strains need, for optimal growth, a pH between 6.5 and 7.5 [50]. The main organic acid that is responsible for honey's acidity is gluconic acid. By analyzing different types of honey, Pauliuc et al. observed that the highest concentration of gluconic acid is found in raspberry honey. The concentration of gluconic acid, thus the $\mathrm{pH}$ of the honey, is influenced by its botanical source [54].

One of the major elements that exhibits inhibitory activity against bacterial growth and proliferation is hydrogen peroxide $\left(\mathrm{H}_{2} \mathrm{O}_{2}\right)$. In order for $\mathrm{H}_{2} \mathrm{O}_{2}$ to be produced, the presence of glucose oxidase (GOx) is required [55-58], but in view of honey's low $\mathrm{pH}$ range, the enzyme is inactive until the honey is diluted. There are several scenarios that could negatively influence the level of $\mathrm{H}_{2} \mathrm{O}_{2}$ in honey. For instance, by exposing to heat, the GOx could be inactivated, but also, a catalase enzyme present in the pollen could deteriorate the 
$\mathrm{H}_{2} \mathrm{O}_{2}$. Additionally, as it was expected, the level of GOx influences the $\mathrm{H}_{2} \mathrm{O}_{2}$ [59]. Another study also highlighted the strong connection between the presence of $\mathrm{H}_{2} \mathrm{O}_{2}$ and the strong antibacterial activity of honey, evidencing at the same time that there are some exceptions that exhibit strong bactericidal activity but have low levels of $\mathrm{H}_{2} \mathrm{O}_{2}$ [60].

It was shown that honeydew honey possesses a very high level of $\mathrm{H}_{2} \mathrm{O}_{2}$ in addition to a great amount of polyphenols [61,62]. Bucekova et al. illustrated that the polyphenols that are found in honey interact with the $\mathrm{H}_{2} \mathrm{O}_{2}$. They showed not only that these interactions lead to a high antibacterial activity, but that they are the key elements responsible for the bacteriostatic and bactericidal properties of honeydew honey [63]. There are several studies that demonstrate that the level of phenolic compounds found in honey is influenced by the botanical and the geographical origin [64-67]. Lachman et al. determined the phenolic contents of different types of honey, analyzing their variation according to the date of harvest (May to August). They revealed that in honey, the highest content of phenolic compounds is found in June [68]. The polyphenols are divided into two classes of compounds, namely, flavonoids and phenolic acids. The determination of the phenolic composition represents an important tool for honey authentication and classification [69].

Bees possess several antimicrobial peptides that are involved in the innate immune response. The most outstanding antimicrobial peptide is defensin-1 (Def-1) [70-72]. In order to analyze the efficacy of this peptide against several bacterial species, Sojka et al. obtained recombinant Def-1. They successfully demonstrated that Def- 1 inhibits the most common wound pathogens, namely S. aureus and Pseudomonas aeruginosa (P. aeruginosa). On the other hand, Def-1 did not exhibit antibacterial activity against Enterococcus faecalis (E. faecalis) [73]. Furthermore, it has been shown that Def- 1 has an important role in the wound healing process. Specifically, it stimulates the production of matrix metalloproteinase-9 [74], that is, endopeptidase, more specifically, a type IV collagenase, involved in tissue remodeling $[75,76]$.

However, even if $\mathrm{H}_{2} \mathrm{O}_{2}$ is a major player involved in honey's bactericidal activity, upon dilution, Manuka honey does not display a detectable concentration of this element, but exhibits great antibacterial activity [59]. Nevertheless, Manuka honey contains up to $800 \mathrm{mg} / \mathrm{kg}$ of methylglyoxal (MGO) [50]. There are numerous studies that demonstrate that the main element responsible for its antiseptic features is MGO [77-82]. The antibacterial effectiveness of Manuka honey is measured through a ranking system that quantifies the level of MGO present in the natural substance. The ranking system is called the unique Manuka factor (UMF) system [83].

\subsubsection{Antioxidant and Anti-Inflammatory Effect}

Besides the antibacterial activity, honey possesses another great characteristic when it comes to its biomedical applications, namely, it exhibits antioxidative effects [84]. The antioxidative effect has an important role by counteracting the action of oxidant compounds [85]. Because of honey's complex composition, there are several compounds that are responsible for its antioxidative activity, such as phenolic compounds $[86,87]$. It has been demonstrated that the presence of these types of compounds is a key player for the antioxidant activity [69]. However, in addition to the main constituents, there are various elements, such as sugars, proteins and carotenes, that are involved in honey's antioxidative capacity [85]. This extraordinary property is influenced by honey's botanical origin [88]. In this direction, it has been shown that heather honey exhibits great antioxidant activity due to its complex composition [89].

Phenolic compounds are not just involved in the antioxidant capacity of honey, but they are involved in its anti-inflammatory effect $[90,91]$. Even if inflammation represents an important part of the immune response when it comes to cellular injury, there are several scenarios in which it can be extreme and cause severe damages [88]. Along this line, it has been shown that honey is a promising immunomodulatory agent. It exhibits positive results when it comes to suppressing the production of NF-kB, MAPK (transcription factors), IL-6 
and IL-1 $\beta$ (cytokines). On the other hand, regarding the inflammatory mediators, it has been evidenced that honey stimulates their production $[2,92]$.

\subsection{Silk Fibroin as a Biomaterial}

As an emerging field, tissue regeneration represents one of the top priorities for the scientific community. Even though there have been advances in this direction, there are numerous drawbacks, such as the biocompatibility or biodegradability of the materials used for treating or replacing damaged tissues [93].

Silk represents one of the most promising natural biopolymers that exhibit a great potential for biomedical applications and beyond. The main source for this biopolymer is Bombyx mori, which produces silk that displays numerous and unique features. The silk produced by Bombyx mori is composed of two fibers of fibroin and sericin that holds them together by acting like a glue. The fibroin fibers are responsible for the extraordinary features of Bombyx mori silk [94]. As for sericin, it is removed by using a degumming process due the fact that is has been shown that the presence of sericin deteriorates the outstanding mechanical strength and the superior level of biocompatibility exhibited by fibroin [93]. In addition, silk fibroin possesses extraordinary features, such as biodegradability, stiffness and thermal stability $[10,95]$. As for the structure of the fibroin fibers, it includes a complex consisting of a light chain (L-chain) and a heavy chain (H-chain) linked through disulfide bonds [96] and a glycoprotein P25 that is linked to the complex [93]. In the light of this, silk fibroin has received great attention from the scientific community [97]. Its features make silk fibroin the most important candidate for developing hydrogels, sponges, nanofibers, biofilms or nanoparticles in order to make important advances in biomedicine and regenerative medicine [89]. The most important directions of using silk fibroin are wound healing, drug delivery and bone tissue engineering $[93,98]$. There have been performed numerous studies that successfully used silk fibroin-based biomaterials for biomedical applications (Table 6).

Table 6. Silk fibroin-based biomaterials and their applications.

\begin{tabular}{ccc}
\hline Biomaterial & Applicability & References \\
\hline Titanium/Silk fibroin scaffolds & Bone repair & {$[99]$} \\
Silk fibroin nanofibers & Drug delivery system & {$[100]$} \\
Silk fibroin hydrogel & Cancer therapy & {$[101]$} \\
Silk fibroin/xanthan hydrogels & Connective tissue regeneration & {$[102]$} \\
Silk fibroin sheet & Vitrification of oocytes & {$[103]$} \\
Silk fibroin microsphere-nanofiber & Vascular tissue engineering & {$[104]$} \\
Silk fibroin and chitosan scaffolds & Tracheal transplantation & {$[105]$} \\
Silk scaffolds & Craniofacial bone repair & {$[106]$} \\
Silk fibroin/cellulose acetate/ & Cancer therapy & {$[107]$} \\
gold-silver nanoparticles & Controlled drug delivery & {$[108]$} \\
Silk fibroin spheres & Target therapy & {$[109]$} \\
Silk fibroin nanoparticles & Drug delivery system for bone defects & {$[110]$} \\
Silk fibroin hydrogel & Drug delivery and controlled release & {$[111]$} \\
Silk fibroin matrices & Drug delivery for sustained release & {$[112]$} \\
Silk hydrogels & Femur defects & {$[113]$} \\
Silk fibroin scaffolds & Mandibular repair & {$[114]$} \\
Silk fibroin scaffolds & Blood contacting devices & {$[115]$} \\
Silk biofilms &
\end{tabular}

\subsection{Honey-Enhanced Silk Fibroin-Based Biomaterials}

As for using biomaterials in the tissue engineering field, there is an important throwback when it comes to its high susceptibility to infections. In this regard, there are several natural compounds that exhibit antimicrobial activity that can be used together with the biomaterials in order to promote healing processes [45]. There are numerous studies that have described honey as a promising, effective agent in the process of tissue healing. It 
is well known that honey reduces inflammation, stimulates collagen production, and promotes the growth of fibroblasts [2,116-119].

When it comes to bone defects, the most appropriate method for improving or treating them is represented by bone tissue engineering. In this direction, the tissue engineered scaffolds that exhibit the most promising results. The most important biological requirements for an engineered scaffold are biocompatibility and degradability [120]. Silk fibroin fibers meet both requirements [121].

Furthermore, there was performed a study that aimed to compare and analyze the effects of $5 \%$ Manuka honey on two silk fibroin-based biomaterials, namely cryogel and electrospun scaffolds. They pursued to determine the impact of various UMF of Manuka honey on the two biomaterials. In regard to the scaffolds' features, the authors analyzed the pore structure and surface topography with a scanning electron microscope; the porosity was determined by using microcomputed tomography. Moreover, the bacterial clearance and the bacterial adhesion were tested. In addition, the release of glucose and the cytotoxicity were investigated. Their results showed that, regardless of the UMF value of the honey that was incorporated in the scaffolds, there was not an observed significant difference on any of the studied parameters [122].

In this direction, Hixon et al. performed a study and developed scaffolds: specifically, silk fibroin cryogels that contained Manuka honey. They analyzed the effects of Manuka honey on the cryogel scaffold features, namely on the scaffold's porosity, biocompatibility and stability. The maintenance of scaffold's structure and properties has great importance for its applicability in bone engineering. On the other hand, they investigated whether silk fibroin cryogels could represent an ideal delivery and sustained release vehicle for honey. The authors also evaluated if the incorporation of Manuka honey in the cryogels maintained its antimicrobial activity. Their results revealed that by incorporating the Manuka honey, the porosity of the cryogels scaffolds was not affected. The large pores are necessary when it comes to bone repair. Additionally, by adding honey in these biomaterials, the swelling potential and the mechanical properties were optimal. By including 5\% Manuka honey in the silk fibroin scaffolds, honey's antibacterial property was functional. Furthermore, the study's outcome revealed that the antibacterial activity was fulfilled by the sustained release [123].

Another study revealed that the incorporation of honey into silk fibroin substrates inhibits cancer development. The authors analyzed the effect of using this type of biomaterial on precancer and normal fibroblasts. By using the honey/fibroin-based substrate, the cell-cell interaction in precancer fibroblasts, but also the cell-matrix interaction, were low. On the other hand, the same interactions in normal fibroblasts were stronger. There the performance of honey on different concentrations was analyzed $(1 \%-6 \%)$; by using silk fibroin membranes with $2 \%$ honey, the best results were observed. They concluded that the honey-enhanced silk fibroin substrate inhibits the spreading of the precancer cells, illustrating a new direction toward anticancer therapies [124].

Along the same page, Rajput et al., developed honey-blended silk fibroin membranes in order to improve the bio-functionality of silk fibroin biofilms to promote re-epithelization and tissue reconstruction. The results of the study showed that when high concentrations of honey are used together with silk fibroin, there is a great molecular affinity between the two elements. Furthermore, by including honey, the silk fibroin membranes exhibit a higher level of water retention than when silk fibroin is used alone. By analyzing the biocompatibility of honey-enhanced silk fibroin membranes, they observed that honey exhibits several extraordinary advantages for this biomaterial; specifically, honey increases cells proliferation, adherence and its viability [125].

In order to develop ideal antimicrobial wound dressings, Yang et al. used aqueouselectrospinning to obtain Manuka honey-enhanced silk fibroin matrices. Their results showed that by using Manuka honey, the interaction and the affinity between silk fibroin matrices and cells were enhanced. Herein, once again, the extraordinary antibacterial feature of honey is highlighted. The results confirmed that silk fibroin matrices enhanced 
with Manuka honey exhibit antibacterial activity against several bacterial strains, such as Escherichia coli (E. coli) or P. aeruginosa [126]. Furthermore, it was reported that by adding honey, the wound-healing process was accelerated. Rajput et al. determined that the optimal concentration of honey to be used when it comes to silk fibroin porous scaffolds is $4 \%$. They also confirmed the abovementioned advantages of using honey-enhanced silk fibroin-based biomaterials. In addition, the authors observed that the inclusion of honey in biomaterials leads to minimum scar formation [127].

Moreover, another research study focused on combining silk fibroin together with honey and with the epidermal growth factor (rhEGF) in order to promote the process of healing of diabetic wounds. The authors demonstrated once more that honey exhibits an extraordinary ability to promote the wound-healing process and great antimicrobial activity against E. coli and Staphylococcus epidermidis (S. epidermidis) [128].

\section{Conclusions}

As a natural product, honey exhibits a wide range of positive effects for human health and beyond. Honey's most outstanding property is represented by the antibacterial effect against numerous bacterial strains. Additionally, it has been demonstrated that honey exhibits antibacterial effects on antibiotic-resistant strains [46]. As for the applicability of honey on Bombyx mori's economic traits, it has a positive influence. By including honey in the silkworms' diet, the digestive capacity of Bombyx mori was enhanced [34]. Furthermore, higher weight gain was observed after adding honey into the silkworms' diet. When it comes to cocoon parameters, by dipping the mulberry leaves in an aqueous honey solution, the cocoon is formed earlier, is also heavier and its shape is more uniform [30]. The positive effects of honey on Bombyx mori do not stop here, as it has been revealed that by supplementing the mulberry leaves with honey, the rate of deposited eggs is increased. Moreover, this natural product has a protective effect for silkworms against several diseases [36]. When it comes to future prospects, this review may also lead to new research on the impact of honey on the silkworm gut microbiome, keeping in mind honey's impact on the mouse gut microbiome.

With its extraordinary features, such as the antibacterial, antioxidative and antiinflammatory effects [62,84], honey is currently used to enhance the silk fibroin-based biomaterials that are used in medical practice. There have been several silk fibroin honeyenhanced biomaterials developed, such as Manuka honey-enhanced silk fibroin matrices, silk fibroin cryogels that contain Manuka honey and honey-blended silk fibroin membranes $[123,125]$. As for tissue healing, the advantage of adding honey on the biomaterials used in this regard is the fact that re-epithelization and tissue reconstruction are promoted. In addition, it has been shown that honey amplifies the interaction and the affinity between silk fibroin matrices and cells [126].

This review brings forth an overview of the applicability of honey on Bombyx mori's economic traits and on silk fibroin-based biomaterials. Even if this is a limited subject, it is of great importance and brings together two extraordinary natural products that exhibit significant value for the life science fields: honey and silk. Through its remarkable properties, honey opens new doors for the use of silk fibroin-based biomaterials. This review represents a starting point for future research, for instance, to improve the biological traits of silkworms in order to obtain vast amounts of recombinant proteins or to increase the potential of Bombyx mori as an experimental model for life science fields. To the best of our knowledge, this is the first paper that brings together the main research studies on this topic.

Author Contributions: The authors contributed equally to the manuscript preparation. All authors have read and agreed to the published version of the manuscript.

Funding: This research received no external funding.

Institutional Review Board Statement: Not applicable. 
Informed Consent Statement: Not applicable.

Data Availability Statement: Not applicable.

Conflicts of Interest: The authors declare no conflict of interest.

\section{References}

1. Al-Ghamdi, A.A.; Ansari, M.J. Biological and Therapeutic Roles of Saudi Arabian Honey: A Comparative Review. J. King Saud Univ. Sci. 2021, 33, 101329. [CrossRef]

2. Oryan, A.; Alemzadeh, E.; Moshiri, A. Biological Properties and Therapeutic Activities of Honey in Wound Healing: A Narrative Review and Meta-Analysis. J. Tissue Viability 2016, 25, 98-118. [CrossRef] [PubMed]

3. Samarghandian, S.; Farkhondeh, T.; Samini, F. Honey and Health: A Review of Recent Clinical Research. Pharmacogn. Res. 2017, 121-127. [CrossRef]

4. Anand, S.; Deighton, M.; Livanos, G.; Morrison, P.D.; Pang, E.C.K.; Mantri, N. Antimicrobial Activity of Agastache Honey and Characterization of Its Bioactive Compounds in Comparison with Important Commercial Honeys. Front. Microbiol. 2019, $10,1-16$. [CrossRef]

5. Dezmirean, D.S.; Mărghitaş, L.A.; Fiţ, N.; Chirilă, F.; Gherman, B.; Mărgăoan, R.; Aurori, A.; Bobiş, O. Antibacterial Effect of Heather Honey (Calluna Vulgaris) against Different Microorganisms of Clinical Importance. Bull. Univ. Agric. Sci. Vet. Med. Cluj Napoca Anim. Sci. Biotechnol. 2015, 72. [CrossRef]

6. Wang, W.; Wang, X.; Li, X.; Pu, Q.; Luo, C.; Xu, L.; Peng, X.; Liu, S. Genetic Manipulation of MicroRNAs in the Silk Gland of Silkworm, Bombyx Mori. Biol. Proced. Online 2019, 21, 1-10. [CrossRef]

7. Li, F.; Li, M.; Mao, T.; Wang, H.; Chen, J.; Lu, Z.; Qu, J.; Fang, Y.; Gu, Z.; Li, B. Effects of Phoxim Exposure on Gut Microbial Composition in the Silkworm, Bombyx Mori. Ecotoxicol. Environ. Saf. 2020, 189, 110011. [CrossRef]

8. Ude, A.U.; Eshkoor, R.A.; Zulkifili, R.; Ariffin, A.K.; Dzuraidah, A.W.; Azhari, C.H. Bombyx Mori Silk Fibre and Its Composite: A Review of Contemporary Developments. Mater. Des. 2014, 57, 298-305. [CrossRef]

9. Chen, S.; Liu, M.; Huang, H.; Cheng, L.; Zhao, H.P. Mechanical Properties of Bombyx Mori Silkworm Silk Fibre and Its Corresponding Silk Fibroin Filament: A Comparative Study. Mater. Des. 2019, 181, 1-11. [CrossRef]

10. Nguyen, T.P.; Nguyen, Q.V.; Nguyen, V.-H.; Le, T.-H.; Huynh, V.Q.N.; Vo, D.-V.N.; Trinh, Q.T.; Kim, S.Y.; Van Le, Q. Silk Fibroin-Based Biomaterials for Biomedical. Polymers 2019, 11, 1933. [CrossRef]

11. Abdelli, N.; Peng, L.; Keping, C. Silkworm, Bombyx Mori, as an Alternative Model Organism in Toxicological Research. Environ. Sci. Pollut. Res. 2018, 25, 35048-35054. [CrossRef]

12. Bandyopadhyay, A.; Chowdhury, S.K.; Dey, S.; Moses, J.C.; Mandal, B.B. Silk: A Promising Biomaterial Opening New Vistas Towards Affordable Healthcare Solutions. J. Indian Inst. Sci. 2019, 99, 445-487. [CrossRef]

13. Tsioris, K.; Raja, W.K.; Pritchard, E.M.; Panilaitis, B.; Kaplan, D.L.; Omenetto, F.G. Fabrication of Silk Microneedles for ControlledRelease Drug Delivery. Adv. Funct. Mater. 2012, 22, 330-335. [CrossRef]

14. Lee, O.J.; Kim, J.H.; Moon, B.M.; Chao, J.R.; Yoon, J.; Ju, H.W.; Lee, J.M.; Park, H.J.; Kim, D.W.; Kim, S.J.; et al. Fabrication and Characterization of Hydrocolloid Dressing with Silk Fibroin Nanoparticles for Wound Healing. Tissue Eng. Regen. Med. 2016, 13, 218-226. [CrossRef]

15. Arboleda-Carvajal, A.; González, J.; Franco-Arias, M.H.; Valladares-Torres, L. Comparación de La Citocompatibilidad in Vitro Entre Los Biomateriales, Fibroína y Polipropileno. Rev. Fac. Ing. 2017, 26, 97-107. [CrossRef]

16. Yan, X. Bioelectronics With Enhanced Cell Affinity. Proc. Natl. Acad. Sci. USA 2017, 2017. [CrossRef]

17. Meng, X.; Zhu, F.; Chen, K. Silkworm: A Promising Model Organism in Life Science. J. Insect Sci. 2017, 17. [CrossRef]

18. Tabunoki, H.; Bono, H.; Ito, K.; Yokoyama, T. Can the Silkworm (Bombyx Mori) Be Used as a Human Disease Model? Drug Discov. Ther. 2016, 10, 3-8. [CrossRef]

19. Zhang, X.; Xue, R.; Cao, G.; Pan, Z.; Zheng, X.; Gong, C. Silkworms Can Be Used as an Animal Model to Screen and Evaluate Gouty Therapeutic Drugs. J. Insect Sci. 2012, 12, 1-9. [CrossRef]

20. Tamilselvi, V.; Murugesh, K.A.; Mangammal, P.; Krishnamoorthy, S.V. Effect of Different Honey and Protein Sources on Economic Characters of Silkworm Bombyx Mori L. Int. J. Chem. Stud. 2020, 8, 328-331. [CrossRef]

21. Kadakia, P.U.; Growney Kalaf, E.A.; Dunn, A.J.; Shornick, L.P.; Sell, S.A. Comparison of Silk Fibroin Electrospun Scaffolds with Poloxamer and Honey Additives for Burn Wound Applications. J. Bioact. Compat. Polym. 2018, 33, 79-94. [CrossRef]

22. Samami, R.; Seidavi, A.; Eila, N.; Moarrefi, M.; Ziaja, D.J.; Lis, J.A.; Rubiu, N.G.; Cappai, M.G. Production Performance and Economic Traits of Silkworms (Bombyx Mori L., 1758) Fed with Mulberry Tree Leaves (Morus Alba, Var. Ichinose) Significantly Differ According to Hybrid Lines. Livest. Sci. 2019, 226, 133-137. [CrossRef]

23. Saviane, A.; Toso, L.; Righi, C.; Pavanello, C.; Crivellaro, V.; Cappellozza, S. Rearing of Monovoltine Strains of Bombyx Mori by Alternating Artificial Diet and Mulberry Leaf Accelerates Selection for Higher Food Conversion Efficiency and Silk Productivity. Bull. Insectol. 2014, 67, 167-174.

24. Dong, H.L.; Zhang, S.X.; Tao, H.; Chen, Z.H.; Li, X.; Qiu, J.F.; Cui, W.Z.; Sima, Y.H.; Cui, W.Z.; Xu, S.Q. Metabolomics Differences between Silkworms (Bombyx Mori) Reared on Fresh Mulberry (Morus) Leaves or Artificial Diets. Sci. Rep. 2017, 7, 1-16. [CrossRef] 
25. Villacrés-Granda, I.; Coello, D.; Proaño, A.; Ballesteros, I.; Roubik, D.W.; Jijón, G.; Granda-Albuja, G.; Granda-Albuja, S.; AbreuNaranjo, R.; Maza, F.; et al. Honey Quality Parameters, Chemical Composition and Antimicrobial Activity in Twelve Ecuadorian Stingless Bees (Apidae: Apinae: Meliponini) Tested against Multiresistant Human Pathogens. LWT 2021, 140. [CrossRef]

26. Machado De-Melo, A.A.; de Almeida-Muradian, L.B.; Sancho, M.T.; Pascual-Maté, A. Composición y Propiedades de La Miel de Apis Mellifera: Una Revisión. J. Apic. Res. 2018, 57, 5-37. [CrossRef]

27. Elamine, Y.; Lyoussi, B.; Miguel, M.G.; Anjos, O.; Estevinho, L.; Alaiz, M.; Girón-Calle, J.; Martín, J.; Vioque, J. Physicochemical Characteristics and Antiproliferative and Antioxidant Activities of Moroccan Zantaz Honey Rich in Methyl Syringate. Food Chem. 2021, 339, 128098. [CrossRef]

28. Alvarez-Suarez, J.M. (Ed.) Bee Products_Chemical and Biological Properties; Springer International Publishing: Basel, Switzerland, 2017; pp. 1-306.

29. Bogdanov, S.; Jurendic, T.; Sieber, R.; Gallmann, P. Honey for Nutrition and Health: A Review. J. Am. Coll. Nutr. 2008, 27, 677-689. [CrossRef]

30. Bhatti, M.F.; Azizullah; Shahzadi, N.; Tahir, H.M.; Ali, S.; Zahid, M.T.; Khurshid, R. Effect of Honey (Apis Dorsata [Hymenoptera: Apidae]) on Larval Growth and Silk Cocoon Yield of Bombyx Mori (Lepidoptera: Bombycidae). J. Insect Sci. 2019, 19, 1-5. [CrossRef]

31. Ajibola, A.; Chamunorwa, J.P.; Erlwanger, K.H. Nutraceutical Values of Natural Honey and Its Contribution to Human Health and Wealth. Nutr. Metab. 2012, 9, 1-12. [CrossRef]

32. Pasupuleti, V.R.; Sammugam, L.; Ramesh, N.; Gan, S.H. Honey, Propolis, and Royal Jelly: A Comprehensive Review of Their Biological Actions and Health Benefits. Oxid. Med. Cell. Longev. 2017. [CrossRef]

33. Madhavi, R.; Siva Prasad, S. Impact of Honey-Enriched Mulberry Diet on the Energy Metabolism of the Silkworm, Bombyx Mori. J. Appl. Nat. Sci. 2020, 12, 133-145. [CrossRef]

34. Sivaprasad, S.; Thulasi, N. Determination of Minimum Effective Concentration of Honey for Optimal Growth, Metabolism and Silk Production in The Silkworm, Bombyx Mori. Ind. J. Appl. Res. 2014, 4, 542-545.

35. Thulasi, N.; Sivaprasad, S. Larval Growth, Silk Production and Economic Traits of Bombyx Mori under the Influence of HoneyEnriched Mulberry Diet. J. Appl. Nat. Sci. 2015, 7, 286-292. [CrossRef]

36. Alagumanikumaran, N.; Prema, P. Studies on Evaluation and Improvements of Growth and Economic Parameters of Bombyx Mori (L) Influence under Mr2 Leaves Fortified with Natural Honey. Int. J. Curr. Sci. Res. 2016, 2, 757-765.

37. Gad, A.A. Biological and Physiological Effects of Some Honey Bee Products and Its Mixtures as Nutritional Additives on Two Strains of The Mulberry Silkworm Bombyx Mori. Alex. J. Agric. Res. 2013, 58, 47-52.

38. Mesbah, H.A.; Seehy, M.A.E.; Omaima, M.M. Effect of Food Additives on the Productivity of Silk Worm Bombyx Mori L. Alex. Sci. Exch. J. Int. Q. J. Sci. Agric. Environ. 2013, 34, 228-233. [CrossRef]

39. Mahmoud, M.M.; Mesbah, H.A.; El Sayed, N.A.A. Evaluation of Certain Types of Honey, Essential Botanical Oils and Their Mixtures on the Productivity of the Mulberry Silkworm Bombyx Mori L. Alex. Sci. Exch. J. Int. Q. J. Sci. Agric. Environ. 2012, 33, 65-72. [CrossRef]

40. Saad, M.; Hassan, E.; Saad, I. Comparative Study Of The Effect Of Camphor Honey Bee And Camphor Oil On Some Biological And Productivity Characters Of Mulberry Silkworm, Bombyx Mori L. J. Plant. Prot. Pathol. 2014, 5, 651-658. [CrossRef]

41. Chen, B.; Du, K.; Sun, C.; Vimalanathan, A.; Liang, X.; Li, Y.; Wang, B.; Lu, X.; Li, L.; Shao, Y. Gut Bacterial and Fungal Communities of the Domesticated Silkworm (Bombyx Mori) and Wild Mulberry-Feeding Relatives. ISME J. 2018, 12, $2252-2262$. [CrossRef]

42. Chen, B.; Zhang, N.; Xie, S.; Zhang, X.; He, J.; Muhammad, A.; Sun, C.; Lu, X.; Shao, Y. Gut Bacteria of the Silkworm Bombyx Mori Facilitate Host Resistance against the Toxic Effects of Organophosphate Insecticides. Environ. Int. 2020, 143, 105886. [CrossRef] [PubMed]

43. El-Arab, A.M.E.; Girgis, S.M.; Hegazy, E.M.; El-Khalek, A.B.A. Effect of Dietary Honey on Intestinal Microflora and Toxicity of Mycotoxins in Mice. BMC Complement. Altern. Med. 2006, 6, 6. [CrossRef] [PubMed]

44. Bucekova, M.; Jardekova, L.; Juricova, V.; Bugarova, V.; Di Marco, G.; Gismondi, A.; Leonardi, D.; Farkasovska, J.; Godocikova, J.; Laho, M.; et al. Antibacterial Activity of Different Blossom Honeys: New Findings. Molecules 2019, 24, 1573. [CrossRef] [PubMed]

45. Rossi, M.; Marrazzo, P. The Potential of Honeybee Products for Biomaterial Applications. Biomimetics 2021, 6, 6. [CrossRef]

46. Mama, M.; Teshome, T.; Detamo, J. Antibacterial Activity of Honey against Methicillin-Resistant Staphylococcus Aureus: A Laboratory-Based Experimental Study. Int. J. Microbiol. 2019, 2019. [CrossRef]

47. Mandal, M.D.; Mandal, S. Honey: Its Medicinal Property and Antibacterial Activity. Asian Pac. J. Trop. Biomed. 2011, 1, 154-160. [CrossRef]

48. Almasaudi, S. The Antibacterial Activities of Honey. Saudi J. Biol. Sci. 2020. [CrossRef]

49. Israili, Z.H. Antimicrobial Properties of Honey. Am. J. Ther. 2014, 21, 304-323. [CrossRef]

50. Albaridi, N.A. Antibacterial Potency of Honey. Int. J. Microbiol. 2019, 2019. [CrossRef]

51. Lee, H.; Churey, J.J.; Worobo, R.W. Antimicrobial Activity of Bacterial Isolates from Different Floral Sources of Honey. Int. J. Food Microbiol. 2008, 126, 240-244. [CrossRef]

52. Mato, I.; Huidobro, J.F.; Simal-Lozano, J.; Sancho, M.T. Significance of Nonaromatic Organic Acids in Honey. J. Food Prot. 2003, 66, 2371-2376. [CrossRef] 
53. Ratiu, I.A.; Al-Suod, H.; Bukowska, M.; Ligor, M.; Buszewski, B. Correlation Study of Honey Regarding Their Physicochemical Properties and Sugars and Cyclitols Content. Molecules 2020, 25, 34. [CrossRef]

54. Pauliuc, D.; Dranca, F.; Oroian, M. Antioxidant Activity, Total Phenolic Content, Individual Phenolics and Physicochemical Parameters Suitability for Romanian Honey Authentication. Foods 2020, 9, 306. [CrossRef]

55. Brudzynski, K. A Current Perspective on Hydrogen Peroxide Production in Honey. A Review. Food Chem. 2020, $332,127229$. [CrossRef]

56. Brudzynski, K.; Abubaker, K.; St-Martin, L.; Castle, A. Re-Examining the Role of Hydrogen Peroxide in Bacteriostatic and Bactericidal Activities of Honey. Front. Microbiol. 2011, 2. [CrossRef]

57. Poli, J.P.; Guinoiseau, E.; Luciani, A.; Yang, Y.; Battesti, M.J.; Paolini, J.; Costa, J.; Quilichini, Y.; Berti, L.; Lorenzi, V. Key Role of Hydrogen Peroxide in Antimicrobial Activity of Spring, Honeydew Maquis and Chestnut Grove Corsican Honeys on Pseudomonas Aeruginosa DNA. Lett. Appl. Microbiol. 2018, 66, 427-433. [CrossRef]

58. Lehmann, D.M.; Krishnakumar, K.; Batres, M.A.; Hakola-Parry, A.; Cokcetin, N.; Harry, E.; Carter, D.A. A Cost-Effective Colourimetric Assay for Quantifying Hydrogen Peroxide in Honey. Access Microbiol. 2019, 1. [CrossRef]

59. Majtan, J.; Bohova, J.; Prochazka, E.; Klaudiny, J. Methylglyoxal May Affect Hydrogen Peroxide Accumulation in Manuka Honey through the Inhibition of Glucose Oxidase. J. Med. Food 2014, 17, 290-293. [CrossRef]

60. Bucekova, M.; Bugarova, V.; Godocikova, J.; Majtan, J. Demanding New Honey Qualitative Standard Based on Antibacterial Activity. Foods 2020, 9, 1263. [CrossRef]

61. Farkasovska, J.; Bugarova, V.; Godocikova, J.; Majtan, V.; Majtan, J. The Role of Hydrogen Peroxide in the Antibacterial Activity of Different Floral Honeys. Eur. Food Res. Technol. 2019, 245, 2739-2744. [CrossRef]

62. Brudzynski, K. Effect of Hydrogen Peroxide on Antibacterial Activities of Canadian Honeys. Can. J. Microbiol. 2006, 52, 1228-1237. [CrossRef] [PubMed]

63. Bucekova, M.; Buriova, M.; Pekarik, L.; Majtan, V.; Majtan, J. Phytochemicals-Mediated Production of Hydrogen Peroxide Is Crucial for High Antibacterial Activity of Honeydew Honey. Sci. Rep. 2018, 8, 1-9. [CrossRef] [PubMed]

64. Olas, B. Honey and Its Phenolic Compounds as an Effective Natural Medicine for Cardiovascular Diseases in Humans? Nutrients 2020, 12, 283. [CrossRef] [PubMed]

65. Boussaid, A.; Chouaibi, M.; Rezig, L.; Hellal, R.; Donsì, F.; Ferrari, G.; Hamdi, S. Physicochemical and Bioactive Properties of Six Honey Samples from Various Floral Origins from Tunisia. Arab. J. Chem. 2018, 11, 265-274. [CrossRef]

66. Cheung, Y.; Meenu, M.; Yu, X.; Xu, B. Phenolic Acids and Flavonoids Profiles of Commercial Honey from Different Floral Sources and Geographic Sources. Int. J. Food Prop. 2019, 22, 290-308. [CrossRef]

67. Combarros-Fuertes, P.; Estevinho, L.M.; Dias, L.G.; Castro, J.M.; Tomás-Barberán, F.A.; Tornadijo, M.E.; Fresno-Baro, J.M. Bioactive Components and Antioxidant and Antibacterial Activities of Different Varieties of Honey: A Screening Prior to Clinical Application. J. Agric. Food Chem. 2019, 67, 688-698. [CrossRef]

68. Lachman, J.; Orsák, M.; Hejtmánková, A.; Kovářová, E. Evaluation of Antioxidant Activity and Total Phenolics of Selected Czech Honeys. LWT Food Sci. Technol. 2010, 43, 52-58. [CrossRef]

69. Cianciosi, D.; Forbes-Hernández, T.Y.; Afrin, S.; Gasparrini, M.; Reboredo-Rodriguez, P.; Manna, P.P.; Zhang, J.; Lamas, L.B.; Flórez, S.M.; Toyos, P.A.; et al. Phenolic Compounds in Honey and Their Associated Health Benefits: A Review. Molecules 2018, 23, 2322. [CrossRef]

70. Nolan, V.C.; Harrison, J.; Cox, J.A.G. Dissecting the Antimicrobial Composition of Honey. Antibiotics 2019, 8, 251. [CrossRef]

71. Valachová, I.; Bučeková, M.; Majtán, J. Quantification of Bee-Derived Peptide. Czech J. Food Sci. 2016, 34, 233-243. [CrossRef]

72. Danihlík, J.; Aronstein, K.; Petřivalský, M. Antimicrobial Peptides: A Key Component of Honey Bee Innate Immunity. J. Apic. Res. 2015, 54, 123-136. [CrossRef]

73. Sojka, M.; Valachova, I.; Bucekova, M.; Majtan, J. Antibiofilm Efficacy of Honey and Bee-Derived Defensin-1 on Multispecies Wound Biofilm. J. Med. Microbiol. 2016, 65, 337-344. [CrossRef]

74. Bucekova, M.; Sojka, M.; Valachova, I.; Martinotti, S.; Ranzato, E.; Szep, Z.; Majtan, V.; Klaudiny, J.; Majtan, J. Bee-Derived Antibacterial Peptide, Defensin-1, Promotes Wound Re-Epithelialisation In Vitro and In Vivo. Sci. Rep. 2017, 7, 1-13. [CrossRef]

75. Reiss, M.; Han, Y.; Garcia, E.; Goldberg, M.; Yu, H.; Garner, W. Matrix Metalloproteinase-9 Delays Wound Healing in a Murine Wound Model. Surgery 2010, 147, 295-302. [CrossRef]

76. Yabluchanskiy, A.; Ma, Y.; Iyer, R.P.; Hall, M.E.; Lindsey, M.L. Matrix Metalloproteinase-9: Many Shades of Function in Cardiovascular Disease. Physiology 2013, 28, 391-403. [CrossRef]

77. Mavric, E.; Wittmann, S.; Barth, G.; Henle, T. Identification and Quantification of Methylglyoxal as the Dominant Antibacterial Constituent of Manuka (Leptospermum Scoparium) Honeys from New Zealand. Mol. Nutr. Food Res. 2008, 52, 483-489. [CrossRef]

78. Kwakman, P.H.S.; te Velde, A.A.; de Boer, L.; Vandenbroucke-Grauls, C.M.J.E.; Zaat, S.A.J. Two Major Medicinal Honeys Have Different Mechanisms of Bactericidal Activity. PLoS ONE 2011, 6, e17709. [CrossRef]

79. Majtan, J.; Klaudiny, J.; Bohova, J.; Kohutova, L.; Dzurova, M.; Sediva, M.; Bartosova, M.; Majtan, V. Methylglyoxal-Induced Modifications of Significant Honeybee Proteinous Components in Manuka Honey: Possible Therapeutic Implications. Fitoterapia 2012, 83, 671-677. [CrossRef]

80. Adams, C.J.; Manley-Harris, M.; Molan, P.C. The Origin of Methylglyoxal in New Zealand Manuka (Leptospermum Scoparium) Honey. Carbohydr. Res. 2009, 344, 1050-1053. [CrossRef] 
81. Snow, M.J.; Manley-Harris, M. On the Nature of Non-Peroxide Antibacterial Activity in New Zealand Manuka Honey. Food Chem. 2004, 84, 145-147. [CrossRef]

82. Girma, A.; Seo, W.; SheI, R.C. Antibacterial Activity of Varying UMF-Graded Manuka Honeys. PLoS ONE 2019, 14, e0224495. [CrossRef] [PubMed]

83. Konde, S.; Beena, J.P.; Sahoo, P.; Raj, N.S.; Kumar, N.C. Manuka Honey: A Potent Cariostatic Agent-An in Vitro Study. Int. J. Clin. Pediatr. Dent. 2018, 11, 105-109. [CrossRef] [PubMed]

84. Mandal, S.; Roy, S.; Mandal, M. Exploration of Antibacterial and Antioxidative Property of Two Natural Honey Samples from Malda District, India. Transl. Med. 2016, 6. [CrossRef]

85. Ahmed, S.; Sulaiman, S.A.; Baig, A.A.; Ibrahim, M.; Liaqat, S.; Fatima, S.; Jabeen, S.; Shamim, N.; Othman, N.H. Honey as a Potential Natural Antioxidant Medicine: An Insight into Its Molecular Mechanisms of Action. Oxid. Med. Cell. Longev. 2018, 2018. [CrossRef]

86. Lianda, R.L.P.; Sant'Anna, L.D.; Echevarria, A.; Castro, R.N. Antioxidant Activity and Phenolic Composition of Aqueous Extracts of Honeys and Their Extracts. J. Braz. Chem. Soc. 2008, 23, 55492.

87. Saha, A.; Mandal, S. In Vitro Assessment of Two Commercial Honey Samples for Antibacterial and Antioxidant Activities. Austin J. Trop. Med. Hyg. 2015, 1, 1-5.

88. Nweze, A.J.; Olovo, C.V.; Nweze, I.E.; John, O.O.; Paul, C. Therapeutic Properties of Honey. Honey Anal. New Adv. Chall. 2020, 1-21. [CrossRef]

89. Moise, A.; Liviu, A.M.; Dezmirean, D.; Bobis, O. Nutraceutical Properties of Romanian Heather Honey. Nutr. Food Sci. 2013, 43, 218-227. [CrossRef]

90. Silva, B.; Biluca, F.C.; Gonzaga, L.V.; Fett, R.; Dalmarco, E.M.; Caon, T.; Costa, A.C.O. In Vitro Anti-Inflammatory Properties of Honey Flavonoids: A Review. Food Res. Int. 2021, 141, 110086. [CrossRef]

91. Vallianou, N.G. Honey and Its Anti-Inflammatory, Anti-Bacterial and Anti-Oxidant Properties. Gen. Med. Open Access 2014, 2. [CrossRef]

92. Ranneh, Y.; Akim, A.M.; Hamid, H.A.; Khazaai, H.; Fadel, A.; Zakaria, Z.A.; Albujja, M.; Bakar, M.F.A. Honey and Its Nutritional and Anti-Inflammatory Value. BMC Complement. Med. Ther. 2021, 21, 30. [CrossRef]

93. Sun, W.; Gregory, D.A.; Tomeh, M.A.; Zhao, X. Silk Fibroin as a Functional Biomaterial for Tissue Engineering. Int. J. Mol. Sci. 2021, 22, 1499. [CrossRef]

94. Koh, L.D.; Cheng, Y.; Teng, C.P.; Khin, Y.W.; Loh, X.J.; Tee, S.Y.; Low, M.; Ye, E.; Yu, H.D.; Zhang, Y.W.; et al. Structures, Mechanical Properties and Applications of Silk Fibroin Materials. Prog. Polym. Sci. 2015, 46, 86-110. [CrossRef]

95. Lee, O.J.; Sultan, M.T.; Hong, H.; Lee, Y.J.; Lee, J.S.; Lee, H.; Kim, S.H.; Park, C.H. Recent Advances in Fluorescent Silk Fibroin. Front. Mater. 2020, 7, 1-12. [CrossRef]

96. Jiang, F.; Liu, K.; Zhao, M.; Tao, X.; Hu, X.; Lu, S.; Lu, S. Tunable High-Molecular-Weight Silk Fibroin Polypeptide Materials: Fabrication and Self-Assembly Mechanism. ACS Appl. Bio. Mater. 2020, 3, 3248-3259. [CrossRef]

97. Qi, Y.; Wang, H.; Wei, K.; Yang, Y.; Zheng, R.Y.; Kim, I.S.; Zhang, K.Q. A Review of Structure Construction of Silk Fibroin Biomaterials from Single Structures to Multi-Level Structures. Int. J. Mol. Sci. 2017, 18, 237. [CrossRef]

98. Kundu, B.; Rajkhowa, R.; Kundu, S.C.; Wang, X. Silk Fibroin Biomaterials for Tissue Regenerations. Adv. Drug Deliv. Rev. 2013, 65, 457-470. [CrossRef]

99. Li, X.; Xiong, Y.Z.; Zhang, H.; Gao, R.N. Development of Functionally Graded Porous Titanium/Silk Fibroin Composite Scaffold for Bone Repair. Mater. Lett. 2021, 282, 128670. [CrossRef]

100. Goudarzi, A.; Sadrnezhaad, S.K.; Johari, N. The Prominent Role of Fully-Controlled Surface Co-Modification Procedure Using Titanium Nanotubes and Silk Fibroin Nanofibers in the Performance Enhancement of $\mathrm{Ti}_{6} \mathrm{Al}_{4} \mathrm{~V}$ Implants. Surf. Coat. Technol. 2021, 412, 127001. [CrossRef]

101. Qian, K.Y.; Song, Y.; Yan, X.; Dong, L.; Xue, J.; Xu, Y.; Wang, B.; Cao, B.; Hou, Q.; Peng, W.; et al. Injectable Ferrimagnetic Silk Fibroin Hydrogel for Magnetic Hyperthermia Ablation of Deep Tumor. Biomaterials 2020, 259, 120299. [CrossRef]

102. Byram, P.K.; Sunka, K.C.; Barik, A.; Kaushal, M.; Dhara, S.; Chakravorty, N. Biomimetic Silk Fibroin and Xanthan Gum Blended Hydrogels for Connective Tissue Regeneration. Int. J. Biol. Macromol. 2020, 165, 874-882. [CrossRef]

103. Nakayama, K.; Chinen, S.; Teshima, J.; Tamada, Y.; Hirabayashi, M.; Hochi, S. Silk Fibroin Sheet Multilayer Suitable for Vitrification of in Vitro-Matured Bovine Oocytes. Theriogenology 2020, 145, 109-114. [CrossRef]

104. Liu, Q.; Ying, G.; Jiang, N.; Yetisen, A.K.; Yao, D.; Xie, X.; Fan, Y.; Liu, H. Three-Dimensional Silk Fibroin Microsphere-Nanofiber Scaffolds for Vascular Tissue Engineering. Med. Nov. Technol. Devices 2021, 9, 100051. [CrossRef]

105. Zang, M.; Zhang, Q.; Davis, G.; Huang, G.; Jaffari, M.; Ríos, C.N.; Gupta, V.; Yu, P.; Mathur, A.B. Perichondrium Directed Cartilage Formation in Silk Fibroin and Chitosan Blend Scaffolds for Tracheal Transplantation. Acta Biomater. 2011, 7, 3422-3431. [CrossRef]

106. Han, Q.; Yang, P.; Wu, Y.; Meng, S.; Sui, L.; Zhang, L.; Yu, L.; Tang, Y.; Jiang, H.; Xuan, D.; et al. Epigenetically Modified Bone Marrow Stromal Cells in Silk Scaffolds Promote Craniofacial Bone Repair and Wound Healing. Tissue Eng. Part A 2015, 21, 2156-2165. [CrossRef]

107. Arumugam, M.; Murugesan, B.; Pandiyan, N.; Chinnalagu, D.K.; Rangasamy, G.; Mahalingam, S. Electrospinning Cellulose Acetate/Silk Fibroin/Au-Ag Hybrid Composite Nanofiber for Enhanced Biocidal Activity against MCF-7 Breast Cancer Cell Mater. Sci. Eng. C 2021, 123, 112019. [CrossRef] 
108. Wenk, E.; Wandrey, A.J.; Merkle, H.P.; Meinel, L. Silk Fibroin Spheres as a Platform for Controlled Drug Delivery. J. Control. Release 2008, 132, 26-34. [CrossRef]

109. Tian, Y.; Jiang, X.; Chen, X.; Shao, Z.; Yang, W. Doxorubicin-Loaded Magnetic Silk Fibroin Nanoparticles for Targeted Therapy of Multidrug-Resistant Cancer. Adv. Mater. 2014, 26, 7393-7398. [CrossRef] [PubMed]

110. Diab, T.; Pritchard, E.M.; Uhrig, B.A.; Boerckel, J.D.; Kaplan, D.L.; Guldberg, R.E. A Silk Hydrogel-Based Delivery System of Bone Morphogenetic Protein for the Treatment of Large Bone Defects. J. Mech. Behav. Biomed. Mater. 2012, 11, 123-131. [CrossRef] [PubMed]

111. Uebersax, L.; Mattotti, M.; Papalö̈zos, M.; Merkle, H.P.; Gander, B.; Meinel, L. Silk Fibroin Matrices for the Controlled Release of Nerve Growth Factor (NGF). Biomaterials 2007, 28, 4449-4460. [CrossRef] [PubMed]

112. Lovett, M.L.; Wang, X.; Yucel, T.; York, L.; Keirstead, M.; Haggerty, L.; Kaplan, D.L. Silk Hydrogels for Sustained Ocular Delivery of Anti-Vascular Endothelial Growth Factor (Anti-VEGF) Therapeutics. Eur. J. Pharm. Biopharm. 2015, 95, 271-278. [CrossRef]

113. Meinel, L.; Betz, O.; Fajardo, R.; Hofmann, S.; Nazarian, A.; Cory, E.; Hilbe, M.; McCool, J.; Langer, R.; Vunjak-Novakovic, G.; et al. Silk Based Biomaterials to Heal Critical Sized Femur Defects. Bone 2006, 39, 922-931. [CrossRef]

114. Jiang, X.; Zhao, J.; Wang, S.; Sun, X.; Zhang, X.; Chen, J.; Kaplan, D.L.; Zhang, Z. Mandibular Repair in Rats with Premineralized Silk Scaffolds and BMP-2-Modified BMSCs. Biomaterials 2009, 30, 4522-4532. [CrossRef]

115. Lau, K.; Waterhouse, A.; Akhavan, B.; Gao, L.; Kim, H.N.; Tang, F.; Whitelock, J.M.; Bilek, M.M.; Lord, M.S.; Rnjak-Kovacina, J. Biomimetic Silk Biomaterials: Perlecan-Functionalized Silk Fibroin for Use in Blood-Contacting Devices. Acta Biomater. 2021. [CrossRef]

116. Maleki, H.; Gharehaghaji, A.A.; Dijkstra, P.J. A Novel Honey-Based Nanofibrous Scaffold for Wound Dressing Application. J. Appl. Polym. Sci. 2013, 127, 4086-4092. [CrossRef]

117. Raynaud, A.; Ghezali, L.; Gloaguen, V.; Liagre, B.; Quero, F.; Petit, J.M. Honey-Induced Macrophage Stimulation: AP-1 and NF-KB Activation and Cytokine Production Are Unrelated to LPS Content of Honey. Int. Immunopharmacol. 2013, 17, 874-879. [CrossRef]

118. Yaghoobi, R.; Kazerouni, A.; Kazerouni, O. Evidence for Clinical Use of Honey in Wound Healing as an Anti-Bacterial, AntiInflammatory Anti-Oxidant and Anti-Viral Agent: A Review. Jundishapur J. Nat. Pharm. Prod. 2013, 8, 100-104. [CrossRef]

119. Tomblin, V.; Ferguson, L.R.; Han, D.Y.; Murray, P.; Schlothauer, R. Potential Pathway of Anti-Inflammatory Effect by New Zealand Honeys. Int. J. Gen. Med. 2014, 7, 149-158. [CrossRef]

120. Wu, J.; Zheng, A.; Liu, Y.; Jiao, D.; Zeng, D.; Wang, X.; Cao, L.; Jiang, X. Enhanced Bone Regeneration of the Silk Fibroin Electrospun Scaffolds through the Modification of the Graphene Oxide Functionalized by BMP-2 Peptide. Int. J. Nanomed. 2019, 14, 733-751. [CrossRef]

121. Lin, X.L.; Gao, L.L.; Li, R.; Cheng, W.; Zhang, C.Q.; Zhang, X.Z. Mechanical Property and Biocompatibility of Silk Fibroin-Collagen Type II Composite Membrane. Mater. Sci. Eng. C 2019, 105, 110018. [CrossRef]

122. Hixon, K.R.; Lu, T.; McBride-Gagyi, S.H.; Janowiak, B.E.; Sell, S.A. A Comparison of Tissue Engineering Scaffolds Incorporated with Manuka Honey of Varying UMF. Biomed. Res. Int. 2017, 2017. [CrossRef]

123. Hixon, K.R.; Lu, T.; Carletta, M.N.; McBride-Gagyi, S.H.; Janowiak, B.E.; Sell, S.A. A Preliminary in Vitro Evaluation of the Bioactive Potential of Cryogel Scaffolds Incorporated with Manuka Honey for the Treatment of Chronic Bone Infections. J. Biomed. Mater. Res. Part B Appl. Biomater. 2018, 106, 1918-1933. [CrossRef]

124. Rajput, M.; Bhandaru, N.; Anura, A.; Pal, M.; Pal, B.; Paul, R.R.; Chatterjee, J.; Mukherjee, R. Differential Behavior of Normal and Fibrotic Fibroblasts under the Synergistic Influence of Micropillar Topography and the Rigidity of Honey/Silk-Fibroin Substrates. ACS Biomater. Sci. Eng. 2016, 2, 1528-1539. [CrossRef]

125. Rajput, M.; Bhandaru, N.; Barui, A.; Chaudhary, A.; Paul, R.R.; Mukherjee, R.; Chatterjee, J. Nano-Patterned Honey Incorporated Silk Fibroin Membranes for Improving Cellular Compatibility. RSC Adv. 2014, 4, 44674-44688. [CrossRef]

126. Yang, X.; Fan, L.; Ma, L.; Wang, Y.; Lin, S.; Yu, F.; Pan, X.; Luo, G.; Zhang, D.; Wang, H. Green Electrospun Manuka Honey/Silk Fibroin Fibrous Matrices as Potential Wound Dressing. Mater. Des. 2017, 119, 76-84. [CrossRef]

127. Rajput, M.; Mandal, M.; Anura, A.; Mukhopadhyay, A.; Subramanian, B.; Paul, R.R.; Chatterjee, J. Honey Loaded Silk Fibroin 3D Porous Scaffold Facilitates Homeostatic Full-Thickness Wound Healing. Materialia 2020, 12. [CrossRef]

128. Sukumar, N.; Ramachandran, T.; Lakshmikantha, C.B. Silk Based Scaffolds in Combination with Honey and RhEGF for Diabetic Wound Healing. Indian Silk 2017, 55, 22-24. 